\title{
A QUESTÃO JUDAICA: A TRANSIÇÃO DO JOVEM MARX DA CRÍTICA FILOSÓFICA À CRÍTICA DA ECONOMIA POLÍTICA
}

\author{
GIANNI FRESU ${ }^{1}$
}

RESUMO: O escrito sobre a questão judaica é de fundamental importância para entender a formação intelectual do jovem Marx, no percurso que o levou da crítica filosófica à crítica da economia política. Nesse trabalho, ele levanta a necessidade de superar a formulação teológica da questão judaica para chegar ao coração da contradição que determina a alienação do homem na sociedade moderna. A capacidade de emancipação do judeu reside na relação do judaísmo com a emancipação do mundo de hoje, não com a simples emancipação do Estado da religião. Na Questão judaica, escrita no outono de 1843 e publicada nos "Anais franco-alemães" de fevereiro de 1844, Marx polemiza com Bauer, afirmando que a completa emancipação do homem não pode limitar-se apenas à emancipação política, mas precisaria atingir as relações sociais e produtivas. O mesmo acontece na Introdução à Crítica da filosofia do direito, também escrita para os Anais franco-alemãs no final de 1843 e publicado em fevereiro de 1844, onde encontramos o definitivo abandono da simples crítica religioso-política e o encaminhar-se da crítica social marxiana. Na Questão judaica e na Introdução, Marx se emancipa completamente da influência de Bauer, portanto, na passagem de 1843 para o 1844, estas três etapas representam momentos essenciais na formação da visão filosófica do jovem Marx.

PALAVRAS-CHAVE: Emancipação política, emancipação humana, crítica social.

ABSTRACT: The writing on the Jewish question is of fundamental importance to understand the intellectual formation of the young Marx in the course that led him from philosophical criticism to the critique of political economy. In this work he raises the need to overcome the theological formulation of the Jewish question to reach the heart of the contradiction that determines the alienation of man in modern society. The Jew's emancipation capacity lies in the relation of Judaism to the emancipation of the world today, not to the mere emancipation of the state of religion. In On the Jewish Question, written in the autumn of 1843 and published in the Franco-German Annals of February 1844, Marx argues with Bauer that the complete emancipation of man cannot be limited to political emancipation alone, but also social and productive one. The same is true in the Introduction to the Critique of Hegel's Philosophy of Right, also written for the Franco-German Annals at the end of 1843 and published in February 1844, where we find the definitive abandonment of simple religious-political critique in the direction to Marxian social criticism. In On the Jewish Question and Introduction, Marx completely emancipates himself from Bauer's influence, so in the passage from 1843 to 1844, these three stages represent essential moments in the formation of the philosophical vision of the young Marx.

KEYWORDS: Political emancipation, human emancipation, social criticism.

\footnotetext{
${ }^{1}$ Professor de filosofia política na Universidade Federal de Uberlândia (UFU). Doutor de Filosofia na Università degli Studi di Urbino “Carlo Bò”. E-mail: giannifresu@ufu.br.
} 
O Jovem Marx mergulhou na filosofia de Hegel, depois de ter largado a sua inicial paixão para a poesia e os estudos jurídicos, tomando consciência da pouca satisfação que lhe suscitou a leitura da obra de Fichte e Kant. Todavia, já as suas primeiras abordagens à obra de Hegel foram bem pouco ortodoxas e mediadas pelo inicial interesse acerca do debate sobre o nascente socialismo utopista ${ }^{2}$. Ele filiou-se ao "Doktor-Club" da Universidade de Berlin onde entrou em contato com o grupo heterogêneo dos jovens hegelianos, entre os quais o Bruno Bauer era a figura mais carismática ${ }^{3}$. Como na dissertação da graduação, que comparava a filosofia de Demócrito à de Epicuro, também no primeiro trabalho do jovem Marx, a Crítica da filosofia do direito de Hegel, encontramos a forte influência de Bauer. Pelo contrário, na Questão judaica, escrita no outono de 1843 e publicada nos "Anais franco-alemães" de fevereiro de 1844, Marx polemiza com Bauer, afirmando que a completa emancipação do homem não pode limitar-se apenas à emancipação política, mas precisaria atingir as relações sociais e produtivas. Isso mesmo acontece na Introdução à Crítica da filosofia do direito, também escrita para os Anais franco-alemãs no final de 1843 e publicado em fevereiro de 1844, onde encontramos o definitivo abandono da simples crítica religioso-política e o encaminharse da crítica social marxiana. Na Questão judaica e na Introdução, Marx se emancipa completamente da influência de Bauer, portanto, na passagem de 1843 para o 1844, estas três etapas representam momentos essenciais na formação da visão filosófica do jovem Marx.

\section{Emancipação da religião e emancipação política.}

Na Alemanha da primeira parte do século XIX ainda existiam restrições legais que limitavam os direitos civis dos judeus, excluídos das profissões públicas da administração. $\mathrm{O}$ próprio pai de Marx foi constrangido à conversão religiosa para exercer a atividade de advogado. Esta limitação, no curso daquela década, levou a uma dura disputa entre conservadores e progressistas: os primeiros em defesa da natureza confessional do Estado alemão; os segundos favoráveis à plena liberdade religiosa e à inclusão dos judeus sem mais limitações na esfera dos direitos civis. Esse argumento foi afrontado por Bruno Bauer em alguns escritos entre 1842 e $1843^{4}$. Segundo Bauer era a natureza cristã do Estado a tornar contraditória a emancipação jurídica dos judeus, que para adquirir a plena cidadania deviam reconhecer uma

\footnotetext{
${ }^{2}$ Giddens, A., Capitalismo e teoria sociale. Marx, Durkheim e Max Weber, Il Saggiatore, Mondadori, 1991, pag. 28

${ }^{3}$ Para aprofundamentos: Moggah D., The philosofi and politics of Bruno Bauer, Cambridge University Press, 2003; Rosen Z. Bruno Bauer and Karl Marx, International Institute of social history, Amsterdam, 1977.

${ }^{4}$ Cfr. Bauer, La questione ebraica, Tomba M. (org.) Manifestolibri, pag. 41-101.
} 
realidade institucional alicerçada nos privilégios dos cristãos. Por um lado, o judeu, até quando fica vinculado à sua religião, não podia viver separado do resto da sociedade, por outro, o cristão, até quando é cristão, não podia abrir mão para conceder os plenos direitos de cidadania aos judeus. Portanto, mais do que aspirar à emancipação particular, os judeus deviam lutar para a emancipação universal, liberando-se dos grilhões do judaísmo. Todavia, segundo ele, os judeus não lutavam para afirmar o Estado laico, mas apenas para obter o reconhecimento do particularismo religioso deles por parte do Estado cristão. A única emancipação possível dos judeus passava não apenas pela eliminação dos limites ao exercício da própria profissão religiosa. Eles deviam emancipar-se tanto do cristianismo quanto do judaísmo, ou seja, chegar à completa libertação dos vínculos religiosos enquanto tais. Na passagem ao ateísmo estava a premissa para a plena emancipação política. Portanto, segundo Bauer, eles deviam juntar-se aos outros cidadãos alemães na luta pelos direitos democráticos. Pelo contrário, até quando sobrevive o Estado confessional não pode existir nenhuma liberdade, nem para os cristãos, nem para os judeus. $\mathrm{O}$ erro estava na reivindicação de um interesse particular, quando era preciso lutar para a afirmação do direito universal da igualdade entre os homens. A emancipação universal só podia acontecer liberando-se o Estado do particularismo de qualquer vínculo religioso, isso teria favorecido o desaparecimento das mesmas religiões e a emancipação integral dos homens das cadeias místicas.

Contra essa posição, Marx apontou algumas contradições da visão de Bauer, criticando a ilusão da emancipação humana apenas na esfera política. Uma polêmica que depois encontramos também nos estudos sobre $A$ ideologia alemã já na primeira página dos rascunhos sobre Feuerbach e a história (que originariamente deviam tornar-se um artigo intitulado Crítica da Caracterização de Ludwig Feuerbach, de Bruno Bauer), onde Marx polemiza com os jovens hegelianos. Eles estavam convencidos de ter produzido um progresso filosófico até "a libertação do homem", mas, pelo contrário, reduziram «a filosofia a teologia, a substância e todo esse lixo à autoconsciência»» ${ }^{5}$. Pelo contrário, segundo Marx

\begin{abstract}
só é possível conquistar a libertação real no mundo real e pelo emprego de meios reais (...) a escravidão não pode ser superada sem a máquina a vapor e a Mule-Jenny (máquina de fiar criada na Inglaterra em 1779 por Samuel Crompton), nem a servidão sem o progresso da agricultura, e que, em geral, não é possível libertar os homens enquanto estes forem incapazes de obter alimentação e bebida, habitação e vestimenta, em qualidade e quantidade adequadas. (...) Para o materialista prático, isto é, para o comunista trata-se de revolucionar o mundo, de enfrentar e de transformar o estado das coisas por eles encontrado ${ }^{6}$.
\end{abstract}

\footnotetext{
${ }^{5}$ Marx K., Engels F., A ideologia alemã, Boitempo, São Paulo, 2007, pag. 29.

${ }^{6}$ Idem pag. 29, 30
} 
$\mathrm{Na}$ Questão judaica, Marx sublinhou como Bauer assumiu acriticamente a representação hegeliana do Estado, considerado uma entidade ética acima das partes em conflito que age para conciliar o particular com o universal. Bauer, escreve Marx, exige por um lado que o judeu largue o judaísmo e, mais em geral, que o homem abandone a religião para tornar-se um ser civilmente emancipado. Por outro lado, ele acredita que a superação política da religião seria equivalente à abolição da religião enquanto tal e à afirmação de um Estado moderno e completo. Exatamente nesse ponto Marx localiza a primeira contradição do raciocínio de Bauer: quando ele afirma que é preciso indagar a espécie de emancipação da qual falamos e as suas condições implícitas, concluindo que «a própria crítica da emancipação política era, de rigor, a crítica final da questão judaica e sua verdadeira dissolução "no problema geral da época" ${ }^{7}$, Bauer coloca questões que não são implícitas à essência da emancipação política. Bauer apontas as suas críticas apenas sobre o Estado cristão, não contra o Estado em geral, dessa maneira ele não investiga o eixo entre emancipação humana e emancipação política, assim levanta condições que se explicam apenas em razão da confusão analítica na abordagem a esses dois níveis. A emancipação política da qual fala Bauer não corresponde à emancipação real, isso é confirmado historicamente do exemplo concreto da democracia americana, um Estado que formalmente não tem natureza confessional, mas onde, todavia, como confirma Tocqueville, o espírito religioso permeia cada aspecto da vida social e política. Assim, a revolução estadunidense fez referência explicita ao "Criador" e à lei "divina", além da "natural", apesar de não assumir diretamente natureza confessional.

A emancipação do Estado da religião não corresponde à emancipação do homem e não coincide com a sua completa liberdade, isso significa que, apesar da natureza laica ou confessional, a contradição é imanente ao Estado enquanto tal, às relações sociais das quais ele é expressão orgânica:

\begin{abstract}
A emancipação política do judeu, do cristão e do homem religioso em geral é a emancipação do Estado do judaísmo, do judaísmo, do cristianismo e, em geral, da religião. De modo particular à sua essência, como Estado, o Estado se emancipa da religião de Estado, isto é, quando o Estado se reconhece muito bem como tal. A emancipação política da religião não é a emancipação da religião de modo radical e isento de contradições, porque a emancipação política não é o modo radical e isento de contradições da emancipação humana. O limite da emancipação política manifesta-se imediatamente no fato de que o Estado pode livrar-se de um limite sem que o homem dele se liberte realmente, no fato de que o Estado pode ser um Estado livre sem que o home seja um homem livre ${ }^{8}$.
\end{abstract}

O fato de que o Estado se emancipe da religião não significa que a maioria dos cidadãos se liberte da religião exatamente porque o primeiro progresso não significa a emancipação plena

\footnotetext{
${ }^{7}$ Marx K., A questão judaica, Editor Moraes, São Paulo, 1991, pag. 19

${ }^{8}$ Idem, pag. 22, 23.
} 
e a superação das contradições que caracterizam a sociedade. Simplesmente a religião torna algo puramente privado, não por isso deixa de ser atividade religiosa. $\mathrm{O}$ homem se liberta por meio do Estado (politicamente) de uma barreira achando-se em contradição consigo mesmo. Trata-se apenas de um subterfúgio através de um meio (o Estado), mesmo que necessário. Para não gerar equívocos, Marx não afirma que a secularização do Estado seja supérflua, ele a considera um progresso, mesmo reafirmando que seria uma pura ilusão considerar essa emancipação política da teologia uma libertação do homem das suas cadeias. Não é a última etapa da emancipação humana em geral, mas a derradeira etapa da emancipação humana dentro do contexto do mundo atual. Marx quer ampliar o discurso, falando da «emancipação real, a emancipação prática» ${ }^{9}$.

Conclui-se, finalmente, ainda quando se proclama ateu por mediação do Estado, isto é, proclamando o Estado ateu, o homem continua sujeito às cadeias religiosas, precisamente porque só se reconhece a si mesmo mediante um subterfúgio, através de um meio. A religião é, cabalmente, o reconhecimento do homem através de um mediador. O Estado é o mediador entre o homem e a sua liberdade. A ascensão política do homem acima da religião partilha de todos os inconvenientes e de todas as vantagens da ascensão política em geral ${ }^{10}$.

A acusação que Marx move a Bauer é que ele nunca saiu da representação ilusória do Estado feita por Hegel, como entidade acima das partes que junta o interesse particular com o universal, porque nunca abordou a sua dimensão material. Novamente, como já aconteceu na Crítica da filosofia do direito de Hegel, encontramos a crítica à concepção hegeliana do Estado e à sua representação das relações entre ele e a sociedade civil. Na dimensão ilusória do Estado político a vida do indivíduo assume o mesmo significado irreal da dimensão religiosa. Enquanto na sociedade civil o egoísmo orienta as atividades humanas no rumo do particularismo, no Estado, como na religião, pelo contrário o homem teria a ilusão de ser parte de uma dimensão universal.

O Estado político acabado é, pela própria essência, a vida genérica do homem em oposição a sua vida material. Todas as premissas desta vida egoísta permanecem de pé à margem da esfera estatal, na sociedade civil, como qualidade desta. Onde o Estado político já atingiu seu verdadeiro desenvolvimento, o homem leva, não só no plano do pensamento, da consciência, mas também no plano da realidade, da vida, uma dupla vida: uma celestial e outra terrena, a vida na comunidade política, na qual ele se considera ser coletivo, e a vida na sociedade civil, em que atua como particular; considera outros homens como meios, degrada-se em joguete de poderes estranhos. O Estado político conduz-se em relação à sociedade civil de modo tão espiritualista como o céu em relação à terra. Acha-se, com relação a ela, em contraposição idêntica e a supera do mesmo modo que a religião, que a limitação do mundo profano, isto é, reconhecendo-a também, de novo, restaurando-a e deixando-se necessariamente dominar por ela. O homem em sua realidade imediata, na sociedade civil, é um ser profano. Aqui, onde passa ante si mesmo e frente aos outros por um indivíduo real, é uma manifestação carente de verdade. Pelo contrário, no Estado, onde o homem é considerado como um ser genérico,

\footnotetext{
${ }^{9}$ Idem, pag. 28.

${ }^{10}$ Idem, pag. 24.
} 
ele é o membro imaginário de uma soberania imaginaria, acha-se despojado de sua vida individual real e dotado de uma generalidade irreal. O conflito entre o homem, como crente de uma religião especial e sua cidadania, e os demais homens enquanto membros da comunidade, reduz-se ao divórcio secular entre o Estado político e a sociedade civil. ${ }^{11}$

Na moderna dimensão do Estado burguês a vida política torna-se apenas uma exceção momentânea e aparente à regra geral que marca a vida do indivíduo, exatamente como antes acontecia na dimensão religiosa em relação à vida cotidiana. Então, a diferença entre o homem religioso e o cidadão é idêntica à diferença entre o comerciante e o cidadão, o trabalhador e o cidadão, o latifundiário e o cidadão, então entre o indivíduo que vive e o cidadão. A contradição que existe entre o homem religioso e o homem político não é diferente daquela entre o burguês e o cidadão.

Bauer, segundo Marx, simplifica a luta secular entre o Estado político e suas premissas, tanto os elementos materiais (a propriedade privada) quanto aqueles espirituais (cultura e religião), desconhecendo a luta entre o interesse geral e o interesse particular, ou seja, «o divórcio entre o Estado político e a sociedade burguesa» ${ }^{12}$, limitando-se a polemizar com a sua expressão religiosa.

O homem se emancipa politicamente da religião ao bani-la do direito público para o direito privado. A religião não é o espírito do Estado, onde o homem ainda que de modo limitado, sob uma forma especial - comporta-se como ser genérico, em comunidade com os outros homens; ela se converte, agora, no espirito da sociedade burguesa, da esfera do egoísmo, no espirito do bellum omnium contra omnes ${ }^{13}$.

\section{Religião e sociedade civil no Estado Laico.}

Segundo Marx, quando a religião se torna atividade só da esfera privada e deixa o Estado para ser pertença exclusiva da sociedade civil, temos a emancipação política do Estado da religião. Isso não significa a superação da religião, mas, sem a resolução das contradições sociais ao fundo da sociedade, pode ser o exato contrário. O Estado cristão perfeito não é o chamado Estado cristão, que reconhece no cristianismo o seu fundamento e a sua religião estatal de forma exclusiva e excludente perante as outras religiões. O Estado cristão perfeito é o Estado ateu, democrático, que relega a religião à sociedade civil. O Estado confessional é, segundo Marx, um Estado ainda incompleto, que utiliza instrumentalmente a religião apenas como meio de legitimação sem transformar, por isso, a religião no efetivo fundamento da vida social acima da qual se eleva o Estado. Trata-se do «Estado da hipocrisia» que ainda não se legitimou por si

\footnotetext{
${ }^{11}$ Pag. 26, 27.

12 Ibidem.

${ }^{13}$ Idem, pag. 28, 29.
} 
mesmo e, portanto, precisa da santificação acima do seu poder, do elo do temporal com Deus e a espiritualidade.

O chamado Estado cristão é, só e simplesmente, o não Estado pois não é possível realizar em criações verdadeiramente humanas o cristianismo como religião, mas, tão somente, o fundamento humano da religião cristã. $\mathrm{O}$ chamado Estado cristão é a negação cristã do Estado, mas, de modo algum, a realização estatal do cristianismo (...) o chamado Estado cristão é o Estado imperfeito deste produto humano. O chamado Estado cristão é o Estado imperfeito e a religião cristã serve de complemento e de instrumento de santificação desta imperfeição. (...) O chamado Estado cristão necessita da religião cristã para aperfeiçoar-se como Estado. O Estado democrático real não necessita da religião para seu aperfeiçoamento político. Pode, ao contrário, prescindir desta, já que nele o fundamento humano da religião se realiza de modo secular. O chamado Estado cristão, por sua vez, conduz-se politicamente em face da religião e religiosamente diante da política. E ao degradar as formas de Estado a mera aparência, degrada igualmente a religião a simples aparência. ${ }^{14}$

Pelo contrário, a secularização torna o espírito religioso verdadeiramente fundamental da vida social, exatamente porque não precisa mais de um Estado guardião da Igreja. O fundamento deste Estado não é o cristianismo, mas o fundamento humano do cristianismo, «a religião continua a ser a consciência ideal, não secular de seus membros, porque é a forma do grau humano de desenvolvimento». Paradoxalmente, na crítica à filosofia de Bauer, Marx volta à lição de Hegel, o qual, na Filosofia da história, explicou o processo que, pelo impulso da reforma religiosa, levou tanto à legitimação do Estado quanto à afirmação da religião como interioridade. Nesse devir, (que antes passa pelas etapas do mundo oriental, grego e romano) o fim do espírito germânico e a Reforma de Lutero seriam a realização da verdade absoluta como infinita autodeterminação da liberdade e sustento do princípio cristão, nesse sentido ele define o «espirito do mundo moderno».

Na Filosofia da história temos três períodos históricos desse mundo caracterizados por três elementos essenciais: o surgimento das nações germânicas; a oposição entre Igreja e Estado; a Reforma religiosa. Ele descreve esses períodos como os reinos do Pai, do filho e do Espírito: «O do Pai é a massa substancial indivisível, em transição como o domínio de Saturno que engole os seus filhos. O reino do filho é o surgimento de Deus somente em relação à existência temporal, refletindo-se nela como algo alheio. O reino do espirito é a reconciliação»» ${ }^{15}$ O primeiro vai do nascimento dos povos germânicos no seio do império romano e do cristianismo até a idade de Carlo Magno, uma fase não particularmente interessante porque caracterizada pela selvageria e inocência desses povos, «surge, então, o mundo cristão como cristianismo, como uma massa, na qual o espiritual e o temporal são apenas diferentes facetas ${ }^{16}$

\footnotetext{
14 Idem, pag. 31.

${ }^{15}$ Hegel G. W. F., Filosofia da história, Editora UNB, Brasília, 1995, pag. 293.

${ }^{16}$ Idem, pag. 292
} 
O segundo é caraterizado por uma dialética que desenvolve essas duas facetas até uma consequente autonomia do poder temporal. A aliança entre Carlo Magno (coroado imperador pelo próprio papa) e a Santa Sé, contra os partidos aristocráticos de Roma, determinou uma estrita ligação entre poder temporal e poder espiritual, mas, apesar disso, segundo Hegel, é exatamente nessa época que começa a desenvolver-se a interioridade do espírito cristão «voltado para o exterior e fora de si». Novamente emerge a visão dialética do filósofo alemão, que localiza na negação dos valores do cristianismo a origem de uma mais profunda e interior espiritualidade religiosa. Isso porque a liberdade cristã se transformou em servidão, tanto sobre o plano religioso, quanto temporal, mas explicitamente Hegel escreve «na mais cruel imoralidade, na desordem e nas brutalidades de todas as paixões». Os elementos mais importantes dessa fase são dois:

O primeiro é a formação dos Estados, que se apresentam numa subordinação da obediência tal que tudo se torna um direito fixo particular, sem o sentido da universalidade. Essa subordinação da obediência aparece no sistema feudal. O segundo aspecto é a oposição entre a Igreja e o Estado. Ela existe porque a Igreja deveria administrar o sagrado, rebaixa-se ao temporal, e assim este poder mostra-se de uma maneira mais desprezível, porque todas as paixões encontram a justificativa na religião $0^{17}$.

A partir dessa contradição se determina o conflito que marca dramaticamente a cristandade na primeira metade do século XVI. O conflito entre o império de Carlo V e a Santa Sé, que chegou até a conquista e destruição da capital da cristandade pelas tropas do Imperador no maio de 1527 , teve origem na contradição entre os dois poderes e na luta para o predomínio entre eles. Por um lado, a Igreja defendia o próprio poder temporal e a sua integridade territorial, sem renunciar às suas ingerências nas funções imperiais (ainda mais com a reforma protestante); por outro Carlo V pretendia o apoio da Igreja católica aos seus planos de império universal sobre a Europa. Exatamente nessa temporada ensanguentada pelas guerras e os horrores começa o terceiro período do mundo germânico, fundamental tanto sobre o plano espiritual, com a Reforma luterana, quanto sobre aquele temporal, com a afirmação do Estado moderno secularizado, que se emancipa do vínculo religioso e da legitimação espiritual da sua autoridade. O Estado objetiva o espirito universal chegando à completa consciência de si, do seu próprio direito e da própria moralidade objetiva, reivindicando a sua legalidade, integridade e a atividade do homem:

Surge a consciência do direito de si mesmo pelo restabelecimento da liberdade cristã. O princípio cristão passou pela tremenda disciplina da cultura, e pela Reforma lhes foram devolvidas a sua verdade e a sua realidade. Esse terceiro período vai da Reforma até nossos dias. O princípio do espírito livre tornou-se aqui o pendão do mundo, e a partir dele desenvolvem-se os principais fundamentos da razão. O pensamento formal, o entendimento, já estava formado, mas o pensamento só atingiu a sua verdadeira substância pela reforma,

${ }^{17}$ Ibidem. Pag 292 
pela renascida consciência concreta do livre espírito. Foi só então que o pensamento começou a sua formação; dele foram retirados fundamentos que serviram de base para a reconstrução da lei fundamental do Estado. A vida estatal efetivou-se, assim com consciência conforme à razão. Costumes e origem não tinham mais valor, os diferentes direitos precisaram legitimarse como baseados em princípios sensatos. Só assim a liberdade do espirito alcança a realidade ${ }^{18}$.

Esse processo que determina o reciproco autonomizar-se das duas esferas leva ao desenvolvimento da religiosidade como escolha de liberdade interior, que na dimensão espiritual se traduz nas diferentes manifestações do pensamento, favorecendo o desenvolvimento do livre raciocínio, da ciência, da filosofia e da cultura. Ao mesmo temo, isso favorece a vida do Estado, assim, as suas regras jurídicas e formas institucionais se desenvolvem de forma coerente com os princípios da razão. Isso leva à suprassunção dos privilégios, das desigualdades jurídicas alicerçadas na particularidade, definida pelo nascimento e legitimada apenas pela tradição e os costumes. As regras administrativas, institucionais e jurídicas encontram o seu fundamento apenas na racionalidade dos princípios, assim a liberdade do espírito alcança a realidade objetivando-se na racionalidade do Estado moderno.

A Reforma foi provocada pela profunda decadência da Igreja que, segundo Hegel, abrangia a sua intima essência $\mathrm{O}$ seja, não era apenas um mero problema ocasional fruto de abusos episódicos cuja responsabilidade estava nos erros, na corrupção ou no prevalecer dos interesses particulares dos homens da Igreja. Pelo contrário, tratava-se de uma crise bem mais profunda, orgânica e funcional que não simplesmente envolvia a instituição mesma, mas estava imanente a ela. A decadência da Igreja, o prevalecer da mundaneidade sobre a espiritualidade, que se encaminha quando ela não encontra mais nenhuma oposição, transformou o princípio eclesiástico em pura exterioridade, assim a entidade que devia salvar as almas da decadência fez dessa salvação um instrumento exterior:

A escravidão da autoridade, pois o espírito, havendo renunciado à própria natureza, não é livre, está preso fora de si; a crença em milagres, da maneira mais absurda e mais trivial, pois o divino é considerado de forma esporádica e finita, devendo existir para fins finitos e particulares; por fim, a ganância pelo poder, a luxúria e a devassidão, toda a perversidade da brutalidade e da infâmia, da hipocrisia e da fraude. Tudo isso se encontra na Igreja, pois nela o sensível não é domado nem constituído pela razão; ele se tornou livre, mas só de forma rude e selvagem. Por outro lado, a virtude da Igreja, negativa só em oposição à temporalidade, é apenas abstratamente negativa. Ela não consegue ser moral na vida real e por isso é só fugidia, resignada e inativa na realidade ${ }^{19}$.

Diante da magnificência das obras artísticas e dos orgulhosos monumentos arquitetônicos, realizados com o dinheiro dos cidadãos, o símbolo da exterioridade e do desejo de potência da Igreja, o genuíno espirito religioso cristão se conservou nos corações simples e

\footnotetext{
${ }^{18}$ Ibidem. Pag, 292

${ }^{19}$ Idem, pag. 344.
} 
despretensiosos dos alemães. Assim, quando todo o Ocidente estava voltado para a conquista das Índias Orientais e das Américas, foi um simples monge alemão o protagonista do distanciamento da exterioridade, até desnudar as contradições da Igreja, reconstruindo todos os ensinamentos e reformulando toda a superstição na qual a Igreja se desatendeu ${ }^{20}$.

Lutero elabora a sua doutrina diretamente nas sagradas escrituras, não sendo atingido nas crenças e superstições que se sobrepunham às obras. Uma vez suprimidas as relações de exterioridade, acaba também a separação entre sacerdote e leigo e não precisa mais de uma casta sacerdotal que monopolize a exclusividade dos tesouros espirituais e da verdade. Nessa mudança Hegel localiza a afirmação da liberdade subjetiva que favorece uma outra progressão fundamental do espirito universal antes de realizar-se de forma absoluta no Estado constitucional:

É o coração, a espiritualidade sensível do homem, que pode e deve apoderar-se da verdade essa subjetividade é a de todos os homens. Cada um deve realizar em si mesmo a obra de reconciliação. O espírito subjetivo tem que acolher o espírito da verdade em si e o abrigar. Aqui está a interioridade absoluta da alma, que pertence à religião e ganhou liberdade na Igreja. A subjetividade apodera-se agora do conteúdo objetivo, isto é, da doutrina da Igreja. Na Igreja luterana, a subjetividade e a certeza do indivíduo são tão necessárias quanto a objetividade da verdade. Para os luteranos, a verdade não é um objeto fabricado; é o próprio sujeito que se deve tornar verdadeiro, ao desistir de seu conteúdo particular em troca da verdade substancial e apropriar-se dessa verdade. Dessa forma o espírito subjetivo torna-se livre na verdade, nega a sua particularidade e em sua verdade chega a si mesmo. Assim a liberdade cristã tornou-se real. Quando se coloca a subjetividade meramente no sentimento, sem esse conteúdo, permanece-se na mera vontade natural. Aqui se encontra o novo e último lema em torno do qual os povos se reúnem: a bandeira do espirito livre, que em si mesmo está na verdade - e só nela. Essa é a bandeira à qual servimos e que carregamos. Daquela época até nossos dias, nada mais se realizou ou deve se realizar a não ser cultivar esse princípio no mundo - já que a reconciliação em si e a verdade também se tornam objetivas, segundo a forma. Até a cultura pertence à forma; a cultura é a confirmação da forma universal, e isso é o próprio pensamento. $\mathrm{O}$ direito, a propriedade, a moralidade objetiva, o governo e a constituição, entre outras coisas, têm agora que ser determinados de maneira universal para que sejam adequados e razoáveis ao conceito de livre vontade. Só assim o espírito da verdade pode surgir na vontade subjetiva, na atividade particular da vontade. Se a intensidade do livre espírito subjetivo decide-se pela forma da universalidade, então o espírito objetivo pode se manifestar. Nesse sentido, é preciso compreender que o Estado foi constituído na religião. Estados e leis não são mais do que o surgimento da religião nas relações da realidade. Este é o conteúdo essencial da Reforma: o homem está determinado por si mesmo a ser livre ${ }^{21}$.

A Reforma favoreceu o desenvolvimento e o progresso do espírito, determinando também uma nova relação mais harmônica (Hegel fala explicitamente de reconciliação) entre esfera espiritual e esfera temporal, emancipando-se a primeira do vínculo com a segunda e viceversa.

\footnotetext{
${ }^{20}$ Idem, pag. 345.

${ }^{21}$ Idem, pag. 345-346.
} 
Esta reconciliação do Estado e da Igreja foi espontânea, embora ainda não possamos falar de uma estrutura institucionalmente articulada e sistematicamente organizada, o justo se encontra na dimensão do pensamento. Ao longo do processo histórico abordado por Hegel, como já esclarecido, a Reforma luterana assume um valor central no processo de afirmação da liberdade, impondo o valor da interioridade como libertação religiosa contra a pretensão do poder temporal. O critério absoluto contra toda a autoridade da fé religiosa, das leis positivas, do direito, conseguiu compreender «o conteúdo do próprio espírito em livre presença» ${ }^{22}$.

Sendo a razão o fundamento substancial tanto da consciência como do exterior e do natural, a rígida divisão entre interesse teórico e interesse prático desaparece; nessa conciliação, onde «o pensamento é agora o estágio a que o espírito chegou», reside a mola do grande progresso das ciências. «O espírito reconhece que a natureza, o mundo precisa ter uma razão na existência», assim surge o interesse universal para o conhecimento do mundo moderno que leva à idade do iluminismo:

O universal na natureza são as espécies, os gêneros, a força e o peso, reduzidos às suas manifestações. Assim, a experiencia tornou-se ciência do mundo, pois ela é, por um lado, a percepção, mas também o descobrimento da lei, do interior, da força, ao devolver o existente à sua simplicidade (...). Abriram-se os olhos dos homens, o sentido foi provocado, e o pensamento foi passou a trabalhar e a se esclarecer. As grandes superstições da época depararam-se com as leis da natureza, assim como todas as representações de poderosas forças estranhas que só poderiam ser derrotadas com a magia. Em toda parte, falava-se a respeito disso, não só entre os católicos, mas também entre os protestantes. $\mathrm{O}$ exterior que a Igreja quer relacionar com o sublime é meramente exterior, assim como a hóstia é só trigo, e as relíquias só ossos. Contra essa fé na autoridade foi imposto o domínio do sujeito por si mesmo, e as leis naturais foram reconhecidas como a única ligação do exterior com o exterior. Assim, todos os milagres foram contestados, pois a natureza é um sistema de leis conhecidas e reconhecidas (...) A essas determinações universais, baseadas na consciência presente, nas leis da natureza e em seu conteúdo que é justo e bom, chamou-se de razão; à validade dessas leis chamou-se de iluminismo ${ }^{23}$.

O processo se desenvolve a partir da dimensão teórica e abstrata dos princípios universais, para chegar, depois de ter superado dialeticamente sobre o plano racional as cristalizações das concepções dogmáticas, ao revolucionamento da realidade concreta com as suas regras e instituições:

Este princípio do pensamento surge, inicialmente, em sua universalidade ainda abstrata e repousa no fundamento da contradição e da identidade. O conteúdo é, com isso, posto como finito, e toda a especulação das coisas humanas e divinas é banida e exterminada pelo iluminismo. Se é infinitamente importante que a forma variada seja trazida para a sua simples determinação, sob a forma da universalidade, então esse princípio ainda abstrato não basta ao espírito vivo, à alma concreta. Com esse princípio formalmente absoluto chegamos ao último estágio da história, ao nosso mundo, aos nossos dias. A mundaneidade é o reino espiritual na existência, o reino da vontade que se torna existência ${ }^{24}$.

\footnotetext{
22 Idem, pag. 361.

${ }^{23}$ Idem, pag. 361- 362

${ }^{24}$ Idem, pag. 363.
} 
Depois da negação da autoridade eclesiástica e a sua defesa pelo Concilio de Trento, a unidade da cristandade ficou impossível: por um lado. nos Países reformados bispados, conventos e outras instituições católicas, como aquelas da educação, foram suprimidos, assim como o que ficava do poder temporal da Igreja: por sua vez a Igreja católica tentou segurar a sua rede e articulação eclesial, mas a o mesmo tempo aviou um processo de reforma, apesar do fato de que tudo o que ficou fora do seu princípio foi condenado e perseguido «ingenuamente». Isso teve o efeito de travar o desenvolvimento do catolicismo e determinou a sua definitiva separação do pensamento científico em grande fermento. Pelo contrário, o protestantismo favoreceu esse desenvolvimento sem entrar em contradição com o surgimento do mesmo iluminismo.

\begin{abstract}
A Igreja parou: "Somente até aqui e nada mais!" Ela se separou da florescente ciência e da literatura humanista, e logo teve oportunidade de exprimir sua repugnância pela ciência. O célebre Copérnico descobriu que a Terra e os planetas giravam em torno do sol, mas a Igreja declarou-se contrária a esse progresso. Galileu, numa discussão sobre as razões favoráveis ou desfavoráveis dessa nova descoberta de Copérnico, declarando-se ele mesmo a ela favorável, foi obrigado, de joelhos, a pedir perdão por essa calúnia. A literatura grega não se tornou o fundamento da cultura, e a educação foi entregue aos jesuítas. Dessa forma sucumbe o espírito do mundo católico ${ }^{25}$.
\end{abstract}

Concluindo esse longo aprofundamento complementar, Hegel, na sua descrição filosófica da afirmação da moderna sociedade burguesa, compreende que o processo de secularização torna mais forte o espírito religioso, transformado em interioridade e trazido na esfera da individualidade que encontra a sua completa soberania na sociedade civil. Mas, ao mesmo tempo, fortalece o Estado que não precisa mais da legitimação religiosa para afirmar a sua dimensão ética perante dos cidadãos. É exatamente a argumentação utilizada por Marx na sua polemica com Bauer, para explicar como a emancipação política não corresponde nem ao fim da religião, nem, ainda menos, à completa emancipação do homem, porque não é a religião a verdadeira essência do Estado.

Pelo contrário, ele reafirma que a emancipação política da religião a deixa sobreviver, ainda que não se trate de religião privilegiada ou oficial. A emancipação política leva apenas à superação de uma parte da contradição secular entre Estado político e sociedade burguesa vivida pelo crente de uma determinada religião com sua condição de cidadania. A perfeição do Estado cristão é o Estado que abstrai da religião dos seus cidadãos, mas a emancipação do Estado da religião não é a emancipação do homem real da religião.

Por isto, não dizemos aos judeus, como faz Bauer: não podeis emancipar-vos politicamente se não emancipais radicalmente do judaísmo. Ao contrário, dizemos: podeis emancipar-vos politicamente sem desvincular radical e absolutamente do judaísmo porque a emancipação política não implica em emancipação humana. Quando vós, judeus, quereis a emancipação

${ }^{25}$ Idem, pag. 348. 
política sem vos emancipar humanamente, a meia solução e a contradição não residem em vós, mas na essência e na categoria da emancipação política ${ }^{26}$.

\section{O conteúdo formal das liberdades burguesas.}

Segundo Bauer, escreve Marx, o homem deve renunciar ao privilegio da fé se quiser obter os direitos universais dos homens que se afirmaram com a revolução americana e com a revolução francesa, ou seja os direitos políticos (a liberdade de opinião e o direito de participação à vida da comunidade, como cidadão ativo e sujeito de direito), e a liberdade de consciência, que dizer, o direito de praticar qualquer culto. Tanto na declaração dos direitos dos homens da Revolução francesa, quanto nos princípios constitucionais americanos, a emancipação política dos chamados direitos humanos não seria em contradição com a profíssão religiosa, pelo contrário, o privilégio da fé torna um dos direitos fundamentais do homem.

A afirmação dos princípios dos direitos humanos, caraterísticos das revoluções burguesas, representa um grande progresso na história da humanidade, todavia, Marx sublinha a natureza puramente formal dos conceitos de liberdade e igualdade que afirmaram. A questão social mostrou a contradição entre duas concepções de justiça: a igualdade formal dos cidadãos perante a lei; a igualdade substancial, pela qual a permanência do privilégio e das profundas diferenças econômicas e sociais é limite insuperável para a efetiva possibilidade de exercer o primeiro direito. Assim, Marx escreve que nenhum dos direitos do homem vai além do homem egoísta, do homem enquanto membro da sociedade civil, ou seja, do indivíduo dobrado sobre si mesmo, na sua dimensão privada, separada da comunidade. Trata-se do homem da liberdade negativa como intangibilidade da esfera individual privada por parte do Estado. Na visão liberal da liberdade o problema principal é de limitar o poder do Estado, através de uma estrutura constitucional que freie a sua tendência expansionista, limitando a esfera da sua intervenção ao mínimo possível para deixar todo o restante à iniciativa privada: a visão do Estado gendarme que vigila os equilíbrios espontâneos gerados pelo mercado. A liberdade se configura como direito de fazer e empreender tudo aquilo que não prejudique os outros, o direito do homem à liberdade não é fundado sobre a união do homem com o homem, mas baseia-se na separação do homem em relação ao seu semelhante. Assim a liberdade é o direito do indivíduo delimitado, limitado a si mesmo.

Longe de conceber o homem como um ser genérico, estes direitos, pelo contrário, fazem da própria vida genérica, da sociedade, um marco exterior aos indivíduos, uma limitação de sua independência primitiva. O único nexo que os mantém em coesão é a necessidade natural, a

${ }^{26}$ K. Marx, A questão judaica, Editor Moraes, São Paulo, 1991, pag. 37. 
necessidade e o interesse particular, a conservação de suas propriedades e de suas individualidades opostas ${ }^{27}$.

Os chamados direitos humanos nada mais são do que direitos do membro da sociedade burguesa, isto é, do homem egoísta e separado da comunidade. A dimensão prática da liberdade do homem é o direito à propriedade privada, que, comentando o artigo 16 da Constituição de 1793, assim é definido por Marx:

O direito humano à propriedade privada, portanto, é o direito de desfrutar de seu patrimônio e dele dispor arbitrariamente, sem atender aos demais homens, independentemente da sociedade, é o direito do interesse pessoal. A liberdade individual e esta aplicação sua constituem o fundamento da sociedade burguesa. Sociedade que faz com que todo homem encontre noutros homens não a realização de sua liberdade, mas pelo contrário, a limitação $\operatorname{desta}^{28}$.

A emancipação política avançada por Bauer não questiona minimamente esse quadro geral do direito do homem egoísta, ou seja, do homem burguês, mas pelo contrário fortalece sua dimensão separada que impede a efetiva e integral emancipação humana.

Mas este fato torna-se ainda mais estranho quando verificamos que os emancipadores políticos rebaixam até mesmo a cidadania, a comunidade política ao papel de simples meio para a conservação dos chamados direitos humanos; que, por conseguinte, o citoyen é declarado servo do homem egoísta: degrada-se a esfera comunitária em que atua o homem em detrimento da esfera em que o homem atua como ser parcial; que, finalmente, não se considera como homem verdadeiro e autêntico o homem enquanto cidadão, senão enquanto burguês $^{29}$.

No quadro da declaração do 1793, segundo o mesmo Bauer, a vida política acaba por ser meramente um instrumento que tem por tarefa e fim a vida e a defesa da sociedade civil. $\mathrm{Na}$ afirmação histórica da burguesia, a emancipação política é, ao mesmo tempo, a dissolução da velha sociedade aristocrática feudal, acima da qual se elevava o poder absoluto do monarca. A revolução política é a revolução da sociedade civil que afirma a sua esfera de autonomia do poder político, esvaziando a antiga articulação corporativa da sociedade civil feudal da sua função política. Nessas linhas Marx retoma algumas das argumentações utilizadas na Crítica da filosofia do direito, em polêmica com o "anacronismo de Hegel", para descrever o processo que leva a burguesia a revolucionar todo o sistema das relações políticas com a radical transformação das relações sociais de produção. Como já explicado no escrito do 1843, Marx reafirma que a velha sociedade civil tinha um caráter imediatamente político, ou, seja, as suas componentes, a propriedade privada, a família, o trabalho no quadro da propriedade fundiária feudal, das camadas e das corporações assumiam o significado de elementos da vida do Estado. A relação do indivíduo com a autoridade estatal era determinada através da pertença a esses

\footnotetext{
${ }^{27}$ Idem, pag. 45 .

${ }^{28}$ Idem, pag. 43.

${ }^{29}$ Idem, pag. 45
} 
organismos intermédios, que desenhavam um quadro marcado por sociedades particulares no interior da sociedade feudal, por isso chamada de sociedade por "castas fechadas". Assim as funções e as condições de vida da sociedade civil tinham conteúdo político, ainda que no sentido feudal. Essas articulações excluíam o indivíduo da totalidade estatal, transformando a relação particular da sua corporação com o Estado na sua própria relação universal com a vida do povo, assim como transformavam a sua determinada atividade e situação civil na sua atividade e situação universal.

A revolução política da burguesia derrubou este poder do monarca absoluto elevando os negócios do Estado a negócios do povo, criando o Estado político como entidade universal, ou seja, um Estado que abolia as camadas, as corporações e os privilégios que representavam a fragmentação particular da sociedade feudal, suprimindo o caráter político da sociedade civil:

\begin{abstract}
Rompeu a sociedade civil em suas partes integrantes mais simples: de um lado os indivíduos; do outro, os elementos materiais e espirituais que formam o conteúdo de vida, a situação destes indivíduos. Liberou de suas cadeias o espírito político, que se encontrava cindido, dividido e detido nos diversos compartimentos da sociedade feudal; unindo os frutos dispersos do espírito político e despojando-o de sua perplexidades diante da vida civil, a revolução política fez com que viesse a se constituir - como esfera da comunidade, da incumbência geral do povo - na independência ideal em relação àqueles elementos especiais da vida civil. A atividade determinada de vida e a situação de vida determinada passaram a ter um significado puramente individual. Deixaram de representar a relação geral entre o indivíduo e o conjunto do Estado. Longe disso, a incumbência pública como tal se converteu em incumbência geral de todo o indivíduo, e a função pública como tal se converteu em incumbência geral de todo indivíduo, e a função pública, em sua função geral ${ }^{30}$.
\end{abstract}

A consagração do idealismo do Estado, como entidade acima das partes com a função de afirmar o universal em harmonia com o interesse particular, representou ao mesmo tempo a consagração do materialismo da sociedade civil. A destruição do poder feudal foi simultaneamente a eliminação dos elos que encadeavam o individualismo da sociedade civil. Assim, segundo Marx, a emancipação política foi ao mesmo tempo a emancipação da sociedade civil da política, da aparência de um conteúdo universal. O indivíduo egoísta e atomizado, desvinculado da arregimentação corporativa, é agora o pressuposto do Estado político, que o reconhece como tal afirmando a esfera dos direitos individuais dos homens onde o poder não pode intervir.

Por conseguinte, o homem não se libertou da religião; obteve, isto sim, a liberdade religiosa. Não se libertou da propriedade privada, obteve a liberdade da propriedade. Não se libertou do egoísmo da indústria, obteve a liberdade industrial ${ }^{31}$.

A afirmação da sociedade burguesa representa uma profunda revolução econômica, social e política, assim a constituição do Estado político e a dissolução da sociedade civil na

\footnotetext{
${ }^{30}$ Idem, pag. $48,49$.

${ }^{31}$ Idem, pag. 50.
} 
dimensão independente da individualidade, garantida pelo direito, acontece no mesmo momento em um único ato. Se trata claramente de uma mudança radical determinada por exigências racionais e interesses da nova classe surgida da decomposição da sociedade feudal, todavia o homem independente da sociedade civil (uma absoluta novidade) é apresentado como homem natural e os direitos humanos (mesmos inéditos) são definidos como direitos naturais. É exatamente esta separação que antepõe o interesse particular, acima do qual se articulam as relações sociais, jurídicas, institucionais e as representações filosóficas, o que impede a emancipação humana.

A emancipação é a redução do homem de um lado, a membro da sociedade burguesa, a indivíduo egoísta independente e, de outro, a cidadão do Estado, a pessoa moral. Somente quando o homem real recupera em si o cidadão abstrato e se converte, como homem individual, em ser genérico, em seu trabalho individual e em suas relações individuais; somente quando o homem tenha reconhecido e organizado suas próprias forças como forças sociais e quando, portanto, já não se separa de si a força social sob a forma de força política, somente então se processa a emancipação humana ${ }^{32}$.

\section{Conclusões}

Marx levanta a necessidade de superar a formulação teológica da questão judaica para chegar ao coração da contradição que determina a alienação do homem na sociedade moderna. A capacidade de emancipação do judeu reside na relação do judaísmo com a emancipação do mundo de hoje, não com a simples emancipação do Estado da religião. Este trabalho é um divisor de águas no processo de formação intelectual de Marx, onde a dialética entre a alienação e a emancipação humana torna-se um dos temas mais centrais da sua obra. A perspectiva de Marx dá-se na exigência de tornar possível o pleno desenvolvimento da personalidade humana, superando as condições impostas pela divisão de classe e a especialização do trabalho. Todavia, ainda nessa obra, as reflexões de Marx ficam num âmbito essencialmente filosófico e político, só com Os manuscritos econômico-filosóficos Marx começa um estudo rigoroso da economia política clássica, aprofundando a obra de Smith e Ricardo, chegando dessa maneira à definição essencial do materialismo histórico.

Um estudioso como David McLellan ${ }^{33}$, para fortalecer a importância dessa afirmação, chega a definir os escritos antes dessa virada "estudos pré-marxistas", no sentido de que neles ainda não encontramos nenhuma interpretação da história em termos de classes, modos de

\footnotetext{
32 Idem, pag. 52.

${ }^{33}$ McLellan D., La concezione materialistica della storia, in Storia del marxismo. Il marxismo ai tempi di Marx, vol. 1, Einaudi, Torino, 1978, pag. 37.
} 
produção, análise da relação entre capital e trabalho. Uma afirmação excessiva, talvez provocatória, porque não considera o quanto a passagem da Crítica à filosofia do direito de Hegel à Questão judaica seja fundamental para o surgimento de algumas das principais categorias do materialismo histórico. Exatamente nos mesmos anos dos aprofundamentos críticos sobre Hegel e Bauer conduzidos por Marx, Engels começava seu estudo sobre a realidade da sociedade industrial inglesa com as Linhas de uma crítica da economia política e A situação da classe operaria inglesa, localizando no surgimento da classe operária a força social destinada a assumir o papel geral de transformação da sociedade, até aquele momento desempenhado pela burguesia. Engels investigou particularmente a revolução industrial inglesa, mostrando as profundas transformações sociais e institucionais por ela produzidas, que esvaziaram de conteúdo o velho Estado e a sua organização política. Mas Engels estudou também a economia política clássica, transmitindo esse interesse a Marx, para reconduzir as categorias da política ao âmbito da dimensão econômica. Segundo Engels, Adam Smith teve um grande mérito, desvelou que a economia não era só um setor da atividade do Estado, ele elevou a economia em essência e fim do Estado, reconduzindo, política, partidos, filosofia e religião às categorias econômicas. Essa leitura mostra que o Estado era só uma cobertura da concreta realidade social que se exprime no âmbito da economia com todas as suas atividades produtivas, relações sociais, modalidade de produção e distribuição da riqueza. Assim, Engels chegou ao mesmo resultado de Marx sobre as formas mistificadas da realidade (contestando também a natureza só aparente das liberdades liberais), mas, se Marx obteve esse resultado partindo da filosofia, Engels o fez estudando a economia. O impulso à democratização empurrado pelo movimento dos trabalhadores desmascarava o sistema de privilégios e exclusão social das chamadas liberdades burguesas. Só o socialismo, como êxito de um processo de conquista de consciência da classe operária, não a simples democracia formal, representava a saída das relações de domínio e exploração do homem sobre o homem caraterísticas daquela formação social. O estudo sobre a classe operária inglesa era exatamente funcional a essa tarefa de conhecimento e transformação dessa classe em sujeito protagonista da transformação social. O encontro com Engels (sobre o plano teórico, não só humano) foi, portanto, fundamental na vida de Marx, visto que o primeiro infundiu no segundo o interesse para a economia política e a história econômica. Entre 1842 e 1844, quando estava na Inglaterra para trabalhar na filial inglesa da empresa do pai, Engels conheceu diretamente as dinâmicas de desenvolvimento da sociedade capitalista e começou a estudar a economia política clássica, sintetizando as suas reflexões críticas sobre as características daquela formação econômico-social no ensaio Linhas 
de uma crítica da economia inglesa, que impressionou muito favoravelmente a Marx. A confirmação desse interesse para as investigações econômicas de Engels se encontra nas notas dos Manuscritos econômicos-filosóficos, onde é possível localizar várias referências ao escrito de Engels. Na evolução de Marx da crítica filosófica à crítica da economia política, o papel de Engels fica central, apesar dos juízos polêmicos de alguns estudiosos que subestimam ou diretamente omitem essa centralidade, chegando a considerá-lo o primeiro profanador da obra do filosofo de Trier.

\section{REFERÊNCIAS BIBLIOGRÁFICAS}

Banfi, A. Incontro con Hegel, Argalìa, Urbino, 1965.

Bauer, La questione ebraica, Tomba M. (org.) Manifestolibri

Colletti, L. Intervista politico-filosofica, Laterza, Bari, 1975.

Colletti, L. Il marxismo e Hegel, Laterza, Bari. 1976.

Engels, F. Antidühring, Editori Riuniti, Roma, 1971.

Engels, F. Introduzione a Le lotte di classe in Francia, Editori Riuniti, Roma, 1973.

Engels, F. La situazione della classe operaia in Inghilterra, Edizioni Rinascita, Roma, 1955.

Engels, F. Sul materialismo storico, Editori Riuniti, Roma, 1949

Feuerbach, L. L'essenza del cristianesimo, Feltrinelli, Malanno, 1960.

Feuerbach, L. L'essenza della religione, Einaudi, Torino, 1972.

Feuerbach, L. La filosofia dell'avvenire, Laterza, Bari, 1969.

Feuerbach, L. Spiritualismo e materialismo, Laterza, Bari, 1972

Giddens, A., Capitalismo e teoria sociale. Marx, Durkheim e Max Weber, Il Saggiatore, Mondadori, 1991, pag. 28

Hegel G. W. F. Filosofia da história, Editora UNB, Brasília, 1995.

Hegel G. W. F. Enciclopedia delle scienze filosofiche in compendio, Laterza Bari, 1967.

Hegel G. W. F. Fenomenologia dello spirito, La nuova Italia, Firenze 1960.

Hegel G. W. F. Filosofia del diritto, Vallecchi, Firenze, 1969.

Hegel G. W. F. Scienza della logica, Laterza, Bari, 1968.

Hobsbawm E. J. (org.)Storia del marxismo, vol. I, Il marxismo al tempo di Marx, Einaudi, Torino, 1978.

Holz, H. H. Marx, la storia, la dialettica, La città del sole, Napoli, 1996.

Losurdo, L. L'ipocondria dell'impolitico. La critica di Hegel ieri e oggi, Micella, Lecce, 2001. 
Marx, K.; Engels, F. A ideologia alemã, Boitempo, São Paulo, 2007.

Marx, K. A questão judaica, Editor Moraes, São Paulo, 1991, pag. 19

Marx, K; Engels F. Opere complete, Editori Riuniti, Roma, 1972.

Merker, N. Marxismo e storia delle idee, Editori Riuniti, Roma, 1974.

Merker, N. Ifondamenti e il metodo della filosofia marxiana della storia, Editori Riuniti, Roma, 1998.

Moggah D., The philosofi and politics of Bruno Bauer, Cambridge University Press, 2003;

Rosen Z. Bruno Bauer and Karl Marx, International Institute of social history, Amsterdam, 1977.

Musto, M. L'ultimo Marx, Donzelli editore 2016, Roma

Musto, M. Karl Marx. Biografia intellettuale e politica, Einaudi, Torino, 2018

Petrucciani, R (org.) Il pensiero di Karl Marx. Filosofia, politica, economia, Carocci, Roma, 2018.

Sichirollo, L. La dialettica, Milano, Mondadori, 1983. 